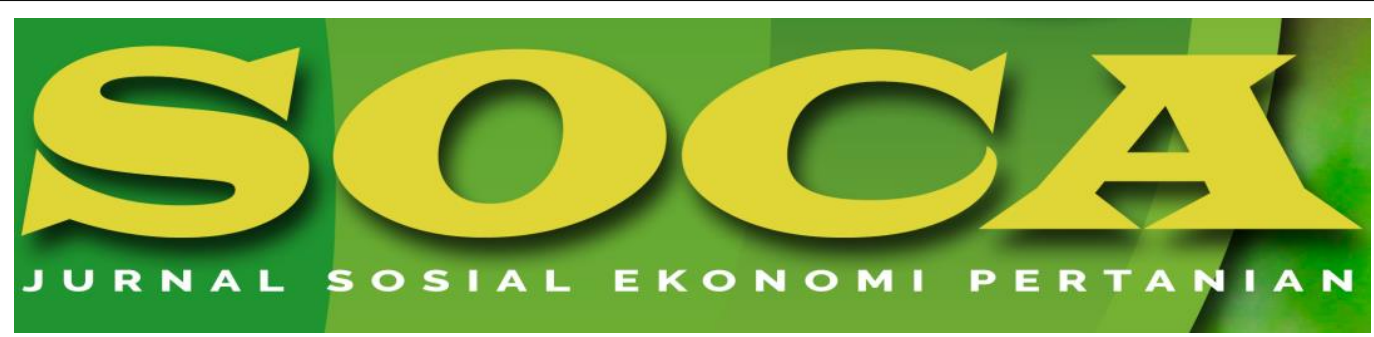

https://ojs.unud.ac.id/index.php/soca

\title{
Factors that Affect the Income of Artisan Palm Sugar Maker in Candimulyo
}

\author{
Dyah Rasti, Agus Setiadi and Kustopo Budiraharjo \\ Agribusiness Department, Animal Husbandry and Agricultural Faculty, \\ Diponegoro University, Semarang, Central Java \\ Email: dyahrasti09@gmail.com \\ Handphone: 085725913873
}

Submitted: March 19th, 2020; Revised: April 5th, 2020; Accepted: April 29th, 2020

\begin{tabular}{|c|c|}
\hline & Abstract \\
\hline \multirow{11}{*}{$\begin{array}{l}\text { Keywords: } \\
\text { factor; palm } \\
\text { sugar; income }\end{array}$} & This study aimed to analyze the income and factors \\
\hline & affecting the income of the artisan palm sugar maker in a \\
\hline & Women Farmer Group (WFG) in Candimulyo District, \\
\hline & $\begin{array}{l}\text { Magelang Regency named Srikandi. This study done from } \\
\text { November } 17 \text { th to December } 15 \text { th, } 2019 \text { in Srikandi WFG, }\end{array}$ \\
\hline & Kebonrejo Village, Candimulyo District, Magelang \\
\hline & $\begin{array}{l}\text { Regency. This study was employing a census method with } \\
\text { a total of } 33 \text { artisan palm sugar maker. The data collection } \\
\text { done by interview, observation, and literature review } \\
\text { technique. Data analyzed by the production cost, revenue } \\
\text { and income, and multiple linear regression analysis. } \\
\text { Results showed that mean sugar palm production, mean } \\
\text { production cost, mean revenue, or mean income was } 2.89\end{array}$ \\
\hline & $\begin{array}{l}\mathrm{kg} / \text { production/day, } \\
\text { volume/day, IDR } 49,068.18 / \text { production volume/day, and }\end{array}$ \\
\hline & IDR $14,942.27 /$ production volume/day. The multiple \\
\hline & linear regression analysis equation was $\mathrm{Y}=1009.844+$ \\
\hline & $979.915 X 1-17798.012 X 2+9330.432 X 3-0.704 X 4+e$. \\
\hline & $\begin{array}{l}\text { The factor of additional material, worker utilization, } \\
\text { production, and fuel cost simultaneously affected the } \\
\text { income. Partially, the worker utilization, production, and } \\
\text { fuel cost affected the income, while the amount of the } \\
\text { additional material didn't affect the income partially. }\end{array}$ \\
\hline
\end{tabular}


How to Cite (APA 6 ${ }^{\text {th }}$ Style):

Rasti, D., Setiadi, A., \& Budiraharjo, K. (2020). Factors that Affect the Income of Artisan Palm Sugar Maker in Candimulyo. SOCA: Jurnal Sosial Ekonomi Pertanian, 14(3), 444-455. https://doi.org/https://doi.org/10.24843/SOCA.2020.v14.i03.p06

\section{INTRODUCTION}

Palm sugar widely developed in Candimulyo District, Magelang Regency. Palm sugar was the most potential commodity in Candimulyo and placed in the first place for the best One Village One Product (OVOP)-based commodity product in Magelang Regency (Raliby \& Rusdjijati, 2016). A palm sugar production center in Candimuyo District was Srikandi WFG that located in Kebonrejo Village. Srikandi WFG built a partnership link with Mega Inovasi Organik (MIO) Company (Inc.) that located in Kulon Progo, Yogyakarta to distribute the palm sugar. The artisan palm sugar maker in Srikandi WFG level of knowledge was still low, therefore there was no posting and income calculation done by the artisan. A study examined the factors affecting the farmer income in developing the palm sugar business was required to increase their level of knowledge.

The palm sugar production in Srikandi WFG was passing down from generation to generation and done traditionally. The production process still involved furnaces and firewood. The challenge in palm sugar production was the random climate change (influenced the quality of the sap) and the condition of the storage that must be always dry. The palm sugar kept on the storage also must be in a dry state, the palm sugar usually heated in an oven to decrease the water content in the palm sugar. Water caused a clumping on the palm sugar, it would need to be dry under the sun to restore the palm sugar from.

Yuroh and Maesaroh (2018) found that the agroindustrial cost, revenue, and income of the palm sugar industry was IDR 85,135.39, IDR 113,232.00, and IDR $28,096.61$, respectively. The production volume, modal, education level, credit, and agricultural extension significantly affected the agroindustrial palm sugar income. While the production volume, education, experience, family size, credit, and extension significantly affected the palm sugar agroindustrial activity.

Study by Khotimah, Kusmiati, and Agustina (2014) stated that the factors that majorly contributed on the artisan palm sugar maker income in Lejejer, Wuluhan District, Jember Regency were fuel cost, the additional material cost, selling price, the production volume, worker's salary, and shared-system used.

A study done by Subekti, Hasanah, and Windani (2018) showed that the oneweek business analysis with the production cost of IDR 313,328.13, production volume of $22.01 \mathrm{~kg}$, and the selling price of IDR $17,000 / \mathrm{kg}$ result in the total of revenue IDR 374,177.08. The profit for the artisan palm sugar maker was IDR $60,484.96$. Feasibility analysis with the $\pi / \mathrm{C}$ was $18.53 \%$ that higher than the bank interest $(0.13 \%)$. This result indicated that this business was feasible to be implemented.

This study aimed to analyze the artisan sugar palm market in Srikandi WFG income and factors affecting the income by examining the amount of the additional material, the worker utilization, production, and the fuel cost. This study was important in developing the production process of the palm sugar from the income 
aspect, hence the method to develop this type of business could be evaluated to maintain the artisan palm sugar maker wellness.

\section{RESEARCH METHODS}

This study conducted on November 17th to December 15th, 2019 on Srikandi Women Farmer Group (WFG) in Kebonrejo Village, Candimulyo District, Magelang Regency. This location chosen because of some considerations: (1) it built in 2012 and (2) palm sugar produced in Candimulyo District was the most potential palm sugar in Magelang Regency due to One Village One Product approach used in the production process. The study was using a census method. The Srikandi WFG consisted of 33 artisan palm sugar makers. The primary and secondary data (from the book, journal, and document) employed in this study. The data collected by the literature review process, interview session with the artisan palm sugar maker, and observation (on the production process of the palm sugar maker and artisan palm sugar maker's activity).

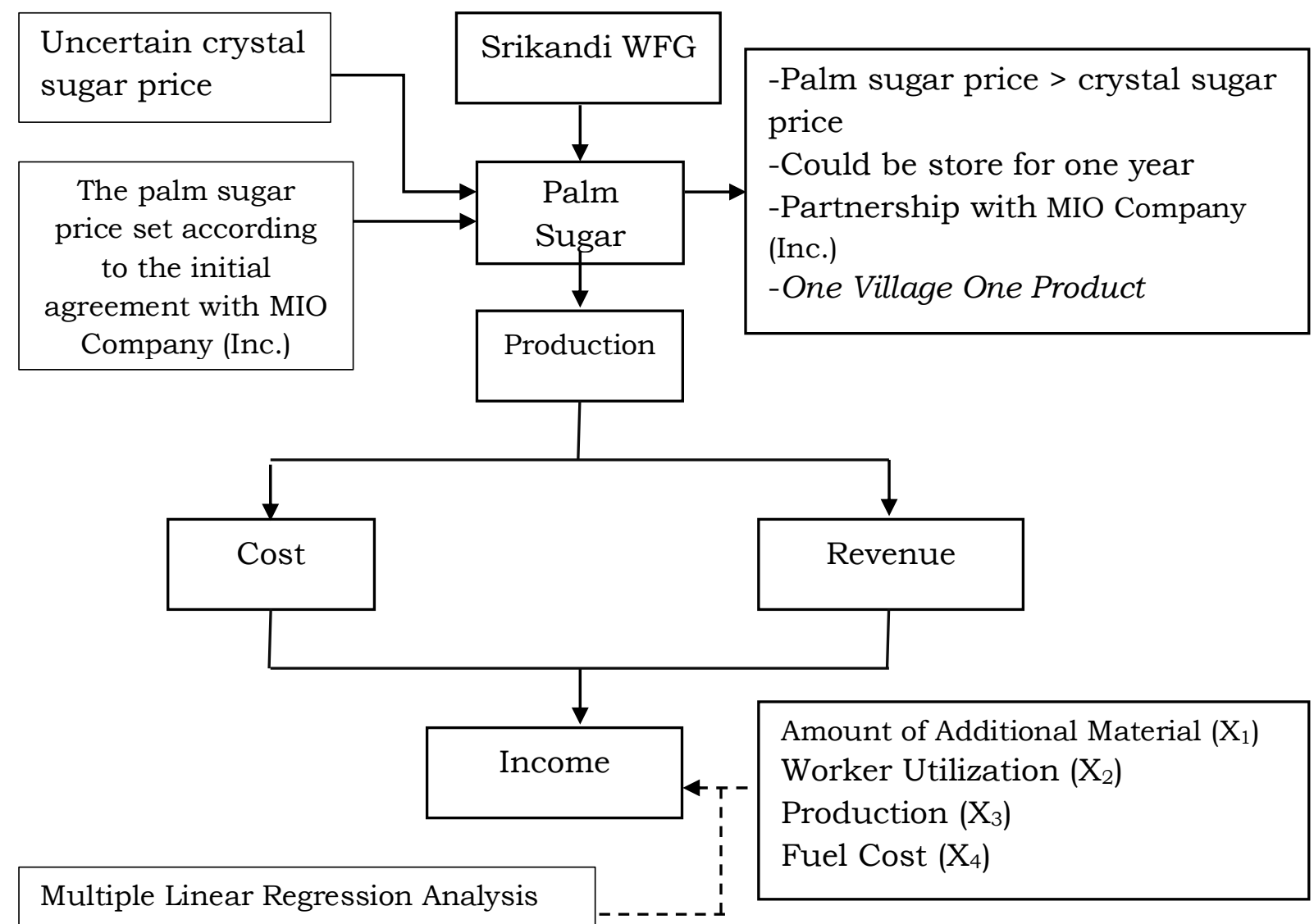

Figure 1. Conceptual Framework

According to Figure 1, the palm sugar production process had the strength and weakness side. The production process required production cost, where the revenue would be obtained from the amount of the palm sugar sales. The cost and revenue then used to analyze the income. The factors affecting this income need to be examined. 
The data analysis employed was the production cost analysis, revenue, and income. The income analysis used showed as follows (Shinta, 2011):

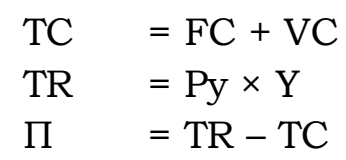

Where

$\begin{array}{ll}\text { TC (Total Cost) } & : \text { Total Cost } \\ \text { FC (Fixed Cost) } & : \text { Fixed Cost } \\ \text { VC (Variable Cost) } & : \text { Variable Cost } \\ \text { TR (Total Revenue) } & : \text { Total Revenue } \\ \text { Py } & : \text { Product Price } \\ \text { Y } & : \text { Number of Product } \\ \Pi & : \text { Income }\end{array}$

The analysis of the factor that affected the income done by multiple linear regression on the variable of the amount of the additional material (X1), worker utilization (X2), production (X3), and fuel cost (X4) to the income (Y). The equation of the multiple linear regression used was (Suliyanto, 2011):

$$
Y=\beta 0+\beta 1\left(X_{1}\right)+\beta 2\left(X_{2}\right)+\beta 3\left(X_{3}\right)+\beta 4\left(X_{4}\right)+e
$$

Where:

Y : Artisan Palm Sugar Maker Income

$\mathrm{X}_{1} \quad$ : The Amount of the Additional Material (Ons)

$\mathrm{X}_{2} \quad$ : Worker Utilization (HKP)

$\mathrm{X}_{3} \quad$ : Production $(\mathrm{kg})$

$\mathrm{X}_{4} \quad$ : Fuel Cost (IDR)

e : Error

B0 : Constanta

$\beta 1-\beta 4:$ variable coefficient

The statistical analysis used were the normality test, classical assumption test, $\mathrm{F}$ test, and $\mathrm{T}$ test.

\section{RESULTS AND DISCUSSION \\ Kebonrejo Village Profile}

Kebonrejo village located in Candimulyo District, Magelang Regency, Central Java Province. The total area of Kebonrejo village was 400 hectares in the coordinate point of $7,5006^{\circ} \mathrm{LS}$ and $110,2832^{\circ} \mathrm{BT}$. The land in the village was in the form of overlay. The latitude of Kebonrejo village was 471 meters above the sea level with the $15^{0}$ slope plain topography (Magelang Regency Institute of Statistical Data, 2018). The border of the area of Kebonrejo was Tegalrejo District on the north side, Pakis and Sawangan District on the east side, Mungkin District on the south side, and Mertoyudan District and Magelang City in the west side. Kebonrejo village consisted of four villages, 8 hamlets/rukun warga, and 17 neighborhoods/rukun tetangga. The population of the Kebonrejo village in 2018 was 2,158 with a total of a male population of 1,105 and a female population of 1.053 with a population density of $906.72 / \mathrm{km}^{2}$ (Magelang Regency Institute of Statistical Data, 2019). The occupation 
of the local community were civil servant, trader, farmer, cattleman, private company employee, state-owned enterprise/regional-owned enterprise staff, worker, and household assistance.

\section{Srikandi Women Farmer Group (WFG) Profile}

Srikandi WFG located in Kebonrejo Village, Candimulyo District, Magelang Regency that formed in 2012. This group leader consisted of 33 active members and lead by Mrs. Susanti. This group produced palm sugar from coconut sap with the mean volume production of $1-5 \mathrm{~kg} /$ worker. The sugar palm submitted to the group with the selling price of IDR $17,000 / \mathrm{kg}$, the group then distributed it to the Mega Inovasi Organik Company (Inc.) in Kulon Progo, Daerah Istimewa Yogyakarta (DIY). The palm sugar could be stored in a long period due to its crystal form. This form also made the packing and transportation easier. This was parallel with the study done by Septiyana, Adnand, Adriansyah, Nurkayanti, and Kurniawan (2019) that stated palm sugar could last for one year (with the water content of 3\%). The sap must be cleaned from the inorganic material. If chemical substance sprayed around the coconut tree tapped, the tapping process must be stopped to prevent contamination on the sap tapped.

The tapping process performed in the morning and evening. If the tapping process conducted in the morning, the sap would be taken in the evening, and vice versa. The tapping process carried by cutting the tip of the coconut flower bunch, then the tip thumped until the sap got out to a bumbung. A lime paste would be added prior to the sap collection to maintain the quality of the sap during the fermentation.

The first step in processing the sap into palm sugar was the filtering process that performed to cleanse the dirt on the sap. The clean sap then heated until the color turn to brown. The sap then stirred until the consistency becoming thicker. After that, it crushed into fine granules. The fine granules then sifted (14 mesh) and stored in a container before it get distributed. The container must be dry and tightly close to prevent the water pressure.

The hindrance found during the production palm sugar was the uncertainty of the climate change. In the dry season, the sap obtained was pure and able to produce high-quality palm sugar, but the amount of sap volume was lower than the volume on the rainy season. In the rainy season, the tree produced a higher amount of sap, but the quality was lower because the rainy season also the time for growth of the plant root. The growth of the plant root made the plant that required more water, hence the sap produced was contained higher water content.

\section{Participant's Characteristic}

According to the data in Table 1, 16 participants (48.48\%) were aged between 31-45 years old. The productive age ranged between 15-55 years of age. The age would affect the participant's physical ability (Wua, 2014). The educational level background of the most participant $(66.67 \%)$ was elementary school. This statistical result showed that there was inadequate concern in the aspect of education in the study location. Education was important to manage the production activity in a business entity. Twenty-nine participant was working for 4-7 years (87.88\%). Longer duration of the production experience would make the worker more skillful in 
managing the business. Puji (2018) stated that the business experience was a factor that contributed to the progress level of the production process. The longer business experienced contributed to the better skill that will be able to produce a better quality of product.

On the number of tree criteria, there were 25 participants tapped 3-7 trees (75.76\%), five participants tapped 8-12 trees (15.15\%), and three participants tapped more than 13 trees $(9.09 \%)$. This result indicated that the number of trees tapped was still low. The higher number of tree tapped resulted in higher sap for the production of the palm sugar. The amount of sap gathered from each tree was also depending on the tree capability in producing the sap. Some trees couldn't produce a high amount of sap. Mugiono, Marwanti, and Awami (2014) also stated that the higher number of tree tapped would contribute to higher sap for the palm sugar production.

The participant's characteristic according to the age, educational level, production duration, and the number of tapped tree is show in Table 1:

Table 1. Participant's Characteristic

\begin{tabular}{|c|c|c|c|}
\hline No & Characteristic & $\begin{array}{c}\text { The Number of } \\
\text { Participant } \\
\text {---(Group Member) --- }\end{array}$ & $\begin{array}{c}\text { Percentage } \\
---\%---\end{array}$ \\
\hline \multirow[t]{6}{*}{1} & Age & & \\
\hline & $<30$ & 2 & 6.06 \\
\hline & $31-45$ & 16 & 48.48 \\
\hline & $46-60$ & 12 & 36.36 \\
\hline & $>61$ & 3 & 9.09 \\
\hline & & 33 & 100.00 \\
\hline \multirow[t]{6}{*}{2} & Educational Level & & \\
\hline & $\begin{array}{l}\text { Didn't Graduate from } \\
\text { Elementary School }\end{array}$ & 2 & 6.06 \\
\hline & Elementary School & 22 & 66.67 \\
\hline & Junior High School & 8 & 24.24 \\
\hline & Senior High School & 1 & 3.03 \\
\hline & & 33 & 100.00 \\
\hline \multirow[t]{4}{*}{3} & Production Duration & & \\
\hline & $0.6-3$ & 4 & 12.12 \\
\hline & $4-7$ & 29 & 87.88 \\
\hline & & 33 & 100.00 \\
\hline \multirow[t]{5}{*}{4} & The Number of Tapped Tree & & \\
\hline & $3-7$ & 25 & 75.76 \\
\hline & $8-12$ & 5 & 15.15 \\
\hline & $>13$ & 3 & 9.09 \\
\hline & & 33 & 100.00 \\
\hline
\end{tabular}

Source: Primary Data (Processed), 2019. 


\section{Production Cost}

The palm sugar production cost consisted of the fixed cost and variable cost as follow:

Table 2. Srikandi WFG Palm Sugar Production Cost at the year of 2019

\begin{tabular}{lcr}
\multicolumn{1}{c}{ Component } & $\begin{array}{c}\text { Mean Cost } \\
\text { IDR/Production/Day }\end{array}$ & $\begin{array}{c}\text { Percentage } \\
\text {---\%--- }\end{array}$ \\
\hline 1. Fixed Cost & & \\
a. Rent & 151.52 & 0.41 \\
b. Land Tax & 2.29 & 0.01 \\
c. Depreciation & 465.45 & 1.36 \\
The Total of Fix Cost & 619.25 & 1.81 \\
2. Variable Cost & & \\
a. Worker & 16,375 & 47.84 \\
b. Sap & $11,863.64$ & 34.66 \\
c. Lime Paste & 468.79 & 1.37 \\
d. Wood & $4,602.27$ & 13.45 \\
e. Coconut Fibrous & 296.97 & 0.87 \\
The Total of Variable Cost & $33,606.67$ & 97.32 \\
The Total of Fixed Cost & $34,225.91$ & 100.00 \\
\hline
\end{tabular}

Source: Primary Data (Processed), 2019.

The mean of the fixed cost was IDR 619.25/production volume/day consisted of rent, land tax, and depreciation. The mean of the variable cost was IDR 33,606.67/ production volume/day consisted of worker salary, sap, lime paste, wood, and coconut fibrous cost. The total production cost was IDR 34,225.91/production volume/day that consisted of the mean of fixed cost and variable cost. The mean production cost used to produce the palm sugar was $2.89 \mathrm{~kg} /$ production volume/day with the total cost of IDR $11,842.88 / \mathrm{kg}$. Production cost used was lower than the production cost on Subekti et al. (2018) study. The study done in Hargorojo Village, Begelen District, Purworejo Regency with the total cost of IDR 313,328.13/week for the $22.01 \mathrm{~kg}$ of production volume (IDR 14,242.19/day). The highest cost spent on the worker salary (47.84\%) with a total of IDR $16,375 /$ production volume/day. The most workers were family worker, the male family member employed to tap the sap, while the female member employed to cook the sap to palm sugar. This was parallel with the study from Saragih, Suharno, and Harianto (2019) that stated, the biggest percentage $(74 \%)$ on the variable cost used to pay the worker according to the regional minimum wage in the study location. A study done by Yuroh and Maesaroh (2018) showed that the production cost (that consisted of tax, depreciation, tree rent cost, capital interest, and variable costs such as sodium bisulfate, wood, plastic, coconut grater, lime paste, worker, and capital interest) needed was IDR 85,135.39. This result indicated that the difference in the production cost happened due to the different components used in the production process and the number of components used. 


\section{Revenue}

Revenue was the gross income obtained by the artisan palm sugar maker according to the multiplication of the volume production and the price set in the market. The price set by the market affected the revenue obtained by the artisan palm sugar maker. The higher price and production volume produced higher revenue. The mean production of the palm sugar was $2.89 \mathrm{~kg} /$ production volume/day with the total of palm sugar price was IDR $17,000 / \mathrm{kg}$, therefore the revenue was IDR 49,068.18/production volume/day. The mean of the palm sugar production was lower than the result from the study of Subekti et al. (2018) that stated palm sugar production reached $22.01 \mathrm{~kg}$ in a week or $3.14 \mathrm{~kg} /$ day and the revenue/week was IDR $374.177,08$ or IDR 53,453.87/day with the total price of IDR $17,000 / \mathrm{kg}$. The study done by Yuroh and Maesaroh (2018) stated that the business revenue was IDR 113,232.00 with the production volume of $9.44 \mathrm{~kg}$ and selling price of IDR $12,000 / \mathrm{kg}$. The farmer revenue on the study done by Khotimah et al. (2014) was IDR $5,605,650 /$ month with a total of volume production of $820 \mathrm{~kg}$ with the selling price of IDR 6,831. The revenue obtained was different due to the difference in the palm sugar production number and price in the study location.

\section{Income}

Income was the revenue obtained from the total of sales reduced by the production cost used. This was parallel with the Soekartawi (2016) that defined income as the profit obtained by the farmer from the difference of the gross revenue (total of product sale) with the costs that have been expended for the production process in the form of money value.

Table 3. Palm Sugar Income in Srikandi WFG at the year 2019

\begin{tabular}{clc}
\hline No & \multicolumn{1}{c}{ Component } & -IDR/Production/Day - \\
\hline 1 & Revenue & $49.068,18$ \\
2 & Production Cost & $34.225,91$ \\
3 & Income & $14.942,27$ \\
\hline
\end{tabular}

Source: Primary Data (Processed), 2019.

According to Table 3, the artisan palm sugar maker revenue, the production cost, and the income was 49,068.18/production volume/day and IDR $34,225.91 /$ production volume/day, and IDR 5,170.34/kg, respectively. This amount of income was higher than the income of the artisan palm sugar maker on the study done by Subekti et al., (2018). The amount of palm sugar maker income in a week was IDR $60,848.96$ with a total production of $22.01 \mathrm{~kg}$ (IDR 2,748.06/kg). Yuroh and Maesaroh (2018) in their study found that the income of the palm sugar production was IDR 28,096.61, while Khotimah et al., (2014) found that the income was IDR $2,380,638 /$ year. This indicated that the farmer group in this study had a small amount of income in comparison with other studies. The difference in the amount of income happened due to the difference in the production cost and revenue. 


\section{Normality Test}

According to the normality test, the value of Asymp. Sig (2 tailed) from the amount of the additional material, production, worker utilization, fuel cost, and income variable was $0.058,0.080,0.126,0.082$, and $0.151 \quad(<0.05)$, respectively. These values indicated that all variable data normally distributed.

\section{Multicollinearity Test}

Below is the result of the multicollinearity test:

Table 4. Multicollinearity Test Result

\begin{tabular}{|c|c|c|c|}
\hline No & Variable & Tolerance & VIF \\
\hline 1 & $\begin{array}{l}\text { The amount of additional } \\
\text { material }\end{array}$ & 0.809 & 1.237 \\
\hline 2 & Worker Utilization & 0.846 & 1.182 \\
\hline 3 & Production & 0.568 & 1.759 \\
\hline 4 & Fuel Cost & 0.755 & 1.324 \\
\hline
\end{tabular}

Source: Primary Data (Processed), 2019.

According to the data in Table 4, the tolerance value for all variable was more than 0.10 and the VIF value less than 10 that indicated there was no multicoleniarity happened.

\section{Autocorrelation Test}

The autocorrelation test produced the Durbin Watson (DW) value. The value of DW, dU, and dL were 1.985, 1.7298, and 1.1927, 4-dU 2.2702, respectively. The DW value located between the $\mathrm{dU}$ and $4-\mathrm{dU}$ which indicated that no autocorrelation found on the data.

\section{Heteroscedasticity Test}

This scatterplot points didn't form a specific pattern. Therefore no heteroscedasticity found in the study data.

\section{Normality of Residual Test}

The residual normality test showed that the value of the Asymp. Sig ( 2 tailed) was 0.867 with the significance value $>0.05$. This result indicated that HO was accepted and Ha refused, therefore the residual normally distributed.

\section{Multiple Linear Regression Analysis}

Multiple linear regression analysis result shows in Table 5:

Table 5. Multiple Linear Regression Analysis Result

\begin{tabular}{llrrc}
\hline No & \multicolumn{1}{c}{ Model } & $\mathrm{B}$ & $\mathrm{t}$ & \multicolumn{1}{c}{ Sig. } \\
\hline & (Constant) & 1009.844 & 0.898 & 0.377 \\
1 & The amount of the additional & 979.915 & 0.138 & $0.891 \mathrm{~ns}$ \\
& material $\left(\mathrm{X}_{1}\right)$ & & & \\
2 & Worker Utilization $\left(\mathrm{X}_{2}\right)$ & -17798.012 & -10.506 & $0.000^{*}$ \\
3 & Production $\left(\mathrm{X}_{3}\right)$ & 9330.432 & 22.893 & $0.000^{*}$
\end{tabular}




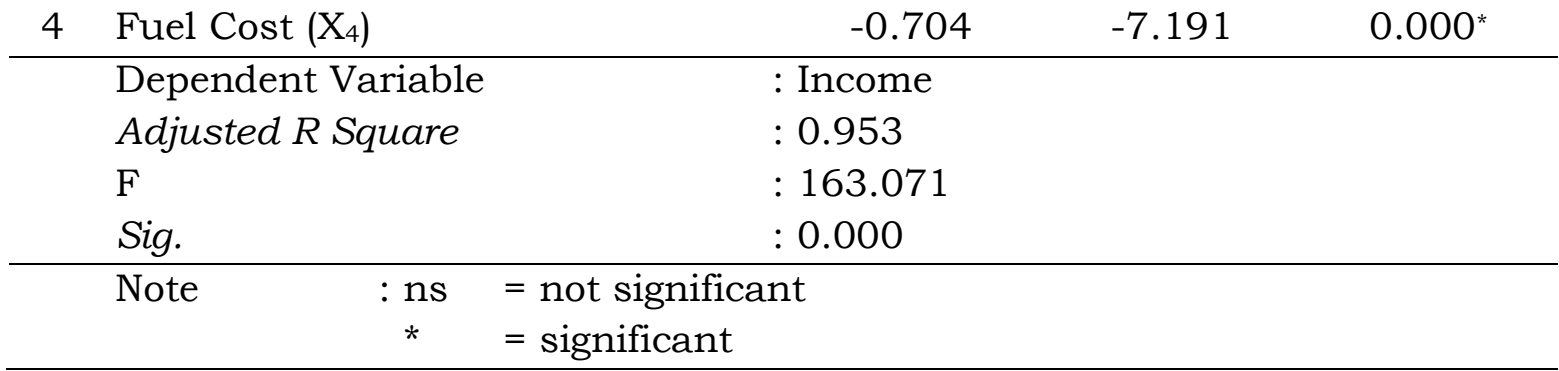

Source: Primary Data (Processed), 2019.

The equation of the multiple linear regression is as follow:

$$
\mathrm{Y}=1009.844+979.915 \mathrm{X}_{1}-17798.012 \mathrm{X}_{2}+9330.432 \mathrm{X}_{3}-0.704 \mathrm{X}_{4}+\mathrm{e}
$$

The significance value of $\mathrm{F}$ was $0.000(\leq 0.05)$. Therefore the independent variable that consisted of the amount of additional material, worker utilization, production, and the fuel cost simultaneously affected the dependent variable (income).

The value of the T-test on the worker utilization, production, and the fuel cost variable was $0.000 \leq 0.05$. This significance value indicated that those variables partially affected the income. The amount of additional material significance value was $0.891>0.05$ which showed that this variable didn't affect the income partially.

The amount of additional material $\left(\mathrm{X}_{1}\right)$ didn't affect the income. The lime paste was used to minimalize the fermentation process prior to the production of sap to palm sugar. The worker utilization $\left(\mathrm{X}_{2}\right)$ affected the amount of income with the value of the regression coefficient of -17798.012 . This value showed that the addition of one worker would contribute to the decrease of the income as much as IDR $17,798.01$. The production variable $\left(\mathrm{X}_{3}\right)$ affected the income with the value of the regression coefficient of 9330.432. This value indicated that the $1 \mathrm{~kg}$ increase of the palm sugar production would increase the income as much as IDR 9,33043. The fuel cost production $\left(\mathrm{X}_{4}\right)$ was affected the income (-0.704), IDR 1 increase of the fuel cost resulted in the decrease of the income as much as IDR 0.704. The value of the Adjusted R Square was 0.953 or $95.3 \%$ that showed the variable of the amount of the additional material, production, and fuel cost could explain the income as much as $95.4 \%$ and $4.7 \%$ affected by the other variables.

\section{CONCLUSION}

We concluded that the mean of production volume, production cost, mean revenue, and the mean income was $2.89 / \mathrm{kg} /$ production volume/day, IDR $34.225,91 /$ production volume/day, IDR 49,068.18/production volume/day, and IDR 14,942.27/production volume/day, respectively. Simultaneously the amount of the additional material, the worker utilization, production, and the fuel cost variable affected the income. Partially, the worker utilization, production, and fuel cost affected the income, while the amount of the additional material didn't affect the income partially. 


\section{RECOMMENDATION}

According to the result of this study, we suggest the artisan palm sugar maker improve their volume production by adding more tapping trees and maintaining the condition of the tree. The farmer group also could create their own packaging to improve the value of their palm sugar product and independently distribute their product, hence it also could contribute to the group fund.

\section{REFERENCES}

Badan Pusat Statistik Kabupaten Magelang. (2018). Kecamatan Candimulyo Dalam Angka 2018. BPS Kabupaten Magelang.

Badan Pusat Statistik Kabupaten Magelang. (2019). Kecamatan Candimulyo Dalam Angka 2019. BPS Kabupaten Magelang.

Khotimah, S., Kusmiati, A., \& Agustina, T. (2014). Analisis Pendapatan Pengrajin Gula Kelapa dan Kontribusinya terhadap Pendapatan Keluarga di Desa Lojejer Kecamatan Wuluhan Kabupaten Jember. Jurnal Sosial Ekonomi Pertanian, $7(2), 45-54$.

Mugiono, Marwanti, S., \& Awami, S. N. (2014). Analisis Pendapatan Usaha Gula Merah Kelapa (Studi kasus Di Desa Medono Kecamatan Kaliwiro kabupaten Wonosobo). Jurnal Mediagro, 10(2), 22-31.

Puji. (2018). Analisis Faktor-Faktor yang Mempengaruhi Produks Gula Kelapa di Desa Karya Tunas Jaya Kecamatan Tempuling Kabupaten Indragiri Hilir. Jurnal Agribisnis UNISI, 7(1), 1-16.

Raliby, O., \& Rusdjijati, R. (2016). Analisis Potensi Unggulan Daerah Kabupaten Magelang Menuju One Village One Product. 769-777.

Saragih, N. F. Y., Suharno, \& Harianto. (2019). Analisis Pendapatan dan FaktorFaktor yang Mempengaruhi Pendapatan Pengrajin Gula Aren di Kabupaten Rejang Lebong Provinsi Bengkulu. Journal of Chemical Information and Modeling, $53(9)$, 1689-1699. https: / / doi.org/10.1017/CBO9781107415324.004

Septiyana, K. R., Adnand, M., Adriansyah, I., Nurkayanti, H., \& Kurniawan, H. (2019). Introduksi Alat Pengering bagi Pengerajin Gula Semut di Desa Kekait Kecamatan Gunung Sari Kabupaten Lombok Barat. Jurnal Imiah Populer, 1(3), 83-90.

Shinta, A. (2011). Ilmu Usahatani. Malang: UB Press.

Soekartawi. (2016). Agribisnis Teori dan Aplikasi. Jakarta: Raja Grafindo Persada.

Subekti, T., Hasanah, U., \& Windani, I. (2018). Analisis usaha industri rumah tangga gula semut organik di desa hargorojo kecamatan bagelen kabupaten purworejo. Surya AGRITAMA, 7(2), 66-79.

Suliyanto. (2011). Ekonometrika Terapam. Yogyakarta: ANDI.

Wua, S. K. (2014). Kajian Usaha Agroindustri Berbahan Baku Nira Aren (Cap Tikus dan Gula Aren) di Desa Tokin Kecamatan Motoling Timur. 5(4). 
Yuroh, F., \& Maesaroh, I. (2018). Faktor-faktor yang Berpengaruh terhadap Pendapatan dan Produktivitas Agroindustri Gula Kelapa di Kabupaten Pangandaran. Jurnal Pemikiran Masyarakat Ilmiah Berwawasan Agribisnis, 4, 254-273. 